\title{
PRINCIPAL PUNISHMENTS ACCORDING TO CRIMINAL CODE OF REPUBLIC OF KOSOVO
}

\author{
Emrush KASTRATI \\ European University of Tirana, Albania. \\ Lawyer in Prishtina \\ emrushkastrati@hotmail.co
}

\section{DOI:10.5901/mjss.2014.v5n19p160}

\begin{abstract}
Types of Principal Punishments. The purpose of the Principal punishment. Conditions to impose the principal punishments

Punishment of long-life imprisonment; Punishment of imprisonment. Punishment of a fine. From judicial practice. The purpose of the punishment as a criminal sanction is that the perpetrator of the criminal of offence after serving the punishment to come back to social life and as a re-socialised and to be integrated actively in the social life. The punishment of long-life imprisonment is exclusively provided for the most aggravated criminal offences and committed under the presence of special aggravated circumstances. The punishment of imprisonment cannot be imposed less than 1 monthnormore than $25 y e a r s$, when imprisonment is imposed up to 6 months, it maybe pronounced in full days. The punishment of a fine may not be less than one hundred (100) European Euros (hereinafter "EUR"). While for other aggravated criminal offences as terrorism etc cannot not exceed twenty five thousand $(25,000)$ EUR or, while when the Punishment of a fine cannot be collected from the convicted person could be substituted with punishment of imprisonment which cannot exceed 3 years.
\end{abstract}

Key words: Principle, long-life, imprisonment, fine, judicial.

\section{The purpose of the punishment}

Looking from historical point of view, from the appearance of the criminal right up to now , the issue of the purpose of the punishment also the legal base of the punishment is in the center of the attention of the theoreticians of the judicial-criminal sciences. The issue of the punishment's purpose is studied in the judicial and philosophic aspect.

Thus the issue of the provision of the punishment with law has posed the question that what in fact should be achieved by imposing and execution of the punishment in the criminal right.

Therefore, the purpose of the punishment is to prevent the perpetrator in the future to commit a criminal offence also to rehabilitate the perpetrator of the criminal offence. Moreover the purpose of the punishment is to influence positively to the others to prevent of committing criminal offence, that the perpetrator of the criminal offence to compensate the victim or the injured party for the lost or the damage that is caused with commitment of the criminal offence. In general aspect, the purpose of the punishment to express the social judgment for the commitment of criminal offence, increase of the moral and enforcement of commitment for respecting of the legal-judicial rules.1.

\section{Types of the punishments}

The Criminal Code of Republic of Kosovo 2 (CCRK), provides the types of the punishments as follows: principle punishments, alternative punishments and accessory punishments. Within the principle punishments, CCRK provides the long-life imprisonment, punishment of imprisonment and punishment of a fine, whilst within the alternative punishments of the CCRK provides suspended punishment, semi-liberty and order for community service work. 


\section{punishment of life long imprisonment}

Criminal legislation which were in force1, did not provide punishment of long-life imprisonment, while CCRK provides this type of punishment as a necessity of time, for the fact that some criminal offences that have been committed were quite serious and under particularly aggravating circumstances Thus CCRK now sanctions the punishment of long-life imprisonment, which is imposed for the most serious criminal offences, whilst it is about the criminal offences that have been committed were quite serious and under particularly aggravating circumstances or criminal offences that have caused serious consequences. Criminal code could not provide long-life imprisonment as the only principle punishment for particular criminal offence. According to CCRK, punishment of long-life imprisonment could not imposed to the person who during the time when the criminal offence was committed the person did not have 21 years old as well to the person who committed the criminal offence has had diminished mental capacity2.

\section{Punishment of imprisonemnt}

If the legal provisions are looked at with the attention, we notice that more that $70 \%$ of the articles for the perpetrators of the criminal offences provide punishment of imprisonment, whilst other legal provisions provide punishment of imprisonment and punishment of fine, whilst in lesser cases is provided of the criminal offences punishment of fine as the only punishment.

The punishment of imprisonment is proved mainly for the serious criminal offences and mainly the court imposes against the perpetrators who committed criminal offences under particularly aggravating circumstances and for these criminal offences where the punishment of imprisonment is provided the only punishment.

In principle the punishment of imprisonment cannot be imposed in duration less that 30 days and more than 25 years.

The punishment of imprisonment is imposed with years months or full days, in the cases when the punishment is imposed with imprisonment up to 6 months, it can be numerically in full days as well 3 .

\section{Punishemnt of fine}

The CCRK except the punishment of imprisonment as principle punishment provides punishment of fine also as principal punishment also. According to CCRK the punishment of fine cannot be less than $100 €$ (on hundred) and cannot be higher than $25.000 €$ (one hundred thousand). But for some criminal offences the Procedure of Republic of Kosovo provides punishment of fine that exceeds $25.000 €$, therefore, for criminal offences related to terrorism, trafficking on human beings, organized crime or criminal offences committed for intention of to obtain a material benefit, the punishment of fine it may not exceed 500,000 euro. (Five hundred thousand) 4. When the court imposes the punishment of fine the court provides the deadline of the payment of the punishment, while the deadline may not be shorter than 15 days and longer than 3 months, while the reasonable circumstances that mainly deal with poor economic situation of the convicted, the court may allow the payment of the punishment of fine in the form of installments while this period may not be longer than two years. In case when the convicted does not want to pay the punishment of fine, or due to aggravating economic conditions cannot pay it, than the court the punishment of fine substitutes with punishment of imprisonment, than one day imprisonment is 20 $€$ (twenty), but the substitution of punishment of fine into punishment of imprisonment regardless the level of highness of the punishment of fine may not exceed more than 3 years 5.

Due to change of economic conditions to the damage of the convicted or if the convicted person does not want or cannot pay the fine entirely, than the court would substitute the remaining part of the fine with punishment of fine calculating one

${ }^{1}$ Criminal Law inOf Kosovo in force from 01.07.1977, Prishtine 1977 ( this law was into force till 05.04.2004) UNMIK Regulation no. 2003/25 dated 06.07.2003 CCK into force from 06.04.2004 till 31.01.2013

${ }^{2}$ Article 44 of CCRK into froce from 01.01.2013, Offical Gazette of Republic of Kosovo

${ }^{3}$ Article 45 of CCRK in force from01.01.2013, Official Gazette nr.19 e dt.13.07.2012.

4Par of Article 46 of Code nr.04/L-082 CCRK in force from dt.01.01.2013 Official Gazetee nr.19 dt.13.07.2012 e dt.13.07.2012.

5Par 3 of Article 46 of CCRK nr.04/L-082 into force dt.01.01.2013 Official Gazette of Republic of Kosovo nr.19 e dt.13.07.2012 
day imprisonment with $20 €$, if the execution of the substitution punishment is done, but the convicted pays the remaining part of the fine then the execution of the punishment is terminated.

As far as the manner substitution punishment of imprisonment concerns, CCRK is convenient for the convicted, thus in the case when the convicted person does not want or due to the economic conditions cannot pay the fine, in that case with the consent of the convicted person the court may instead of the provision of punishment of imprisonment to substitute the punishment of fine with an order for community service work.

The order for community service work is calculated in that manner that 8 hours of the community service work are calculated twenty $20 €$ fine. Regardless of the height of punishment of fine the duration of community service work may not exceed over 240 hours 1.

Having in mind the fact the punishment is dedicated to the particular person, so we have to deal with the individualism of the punishment, than the punishment of fine may not be executed after the death of the convicted person. Therefore, in this case we talk about with the punishment of fine that eventually after the death of the convicted person, somebody from the family attempt to pay the punishment of fine instead of the late convicted person, legally this cannot happen, in this cases the court suspend the procedure of execution.

Always with the consent of the convicted person when the punishment of imprisonment is imposed to the convicted person up to 6 months, the imposed punishment of imprisonment could be substituted with punishment of fine 2 . When the court imposes the order for community service against the convicted person then orders the convicted person to does community service work without payment in a particular time from 30 to 240 working hours. The manner respectively the procedure of this type of the court order for community service work, is set up by probation service for the type of community service work that should be done by the convicted person, afterwards, is set up the particular organization for which the convicted person would do the work for community service work, decides for the days, weeks during this time community service work should be done and supervise the work of community service work. The court has the legal competence to set up time period for doing of community service work, whilst this time cannot be longer than 1 (year). but if for whatever reason after the past of specified time the convicted person did not perform the work for community service or has performed such work partially, then the court substitute the community service work and issues the order of punishment. The substitution would be ordered in such way that one day imprisonment would be ordered for 8 hours work for the community service work which was not performed.

\section{Judicial practice}

The basic Court in Prishtina-Department of Serious Crime, with judgment PKR.nr.24/2013 dated 12.03.2014, five accused persons has found guilty for criminal offences, serious cases of aggravated theft robbery or of robbery from Article 256 par. 2 in conjunction to Article 23 CCK, because during the theft robbery one person died as consequence of use of weapon by the robber. Thus the court one of the accused found guilty and sentences of punishment of imprisonment in duration of 15 years and 6 months, another accused with punishment of imprisonment in duration of 13 years, two of the accused the court sentences with punishment of imprisonment of 10 years for each of them and for the last one sentences with 3 years' imprisonment.

From direct review of the case file we came to the conclusion that the court has mistakenly has executed the material right and as result has violated the law damaging two from five accused. Thus till the court has implemented just the material right against three convicted persons, mistakenly has implemented the material right against the convicted persons of 10 years imprisonment.

The fact that the court has executed mistakenly the material right against of two convicted persons of 10 years, consist in the fact that, their acts did not create the element of criminal offence of theft $n$ nature of robbery or robbery from Article 256 par. 2 in conjunction to Article 23 of CCK and nor any other criminal offence, but the court due to lack of evidence should have waive of criminal responsibility for which they have been accused. The court in fact has found guilty two of the accused

1Par 5 of Article 46 of CCRK nr.04/L-082 into force from.01.01.20130fficial Gazette of Republic of Kosovo nr.19 e dt.13.07.2012. 2Article 47 of CCRK into force from dt.01.01.2013 Official Gazette of Rebublic of Kosovo dt.01.01.2013 does not expplain in which stage of the procedures this legal possibility should ne executed but I consider that this could be by the annoncemnt of the judgement before the start of the execution of the punishment of imprisonment. 
based on the evidence of the first accused, the court has acted in violation to article 159.par.1 par.3 of CPCK1 since here we deal with a privileged witness, so as witness he cannot be interrogated according to subpar. 3 of the abovementioned Article the codefendant till the joint procedure is implemented, while in particular case there was a joint criminal procedure. As well based on the Article 157 par.2.i CPCK does not allow such a possibility to the court to find the accused guilty only based on a statement-evidence, because the paragraph 2 of Article 157 provides - cite: the court does not find guilty the accused based only in one statement. Therefore, in such circumstances while an accused person involves two more accused persons, in compliance with abovementioned Article stated by the Court should not find them guilty the two accused persons who were sentenced.

According to judgment P.nr.446/2013 dated.29.05.2014 the Basic Court in Prishtina-Branch in , the accused who was found guilty and sentenced of punishment of imprisonment in duration of 3 months, while for the criminal offence illegal usurpation of real estate from Article 332 par.1 of CCRK. Making a direct review of the case files we came into conclusion that the court due to lack of evidence should have acquitted the charges against the accused but even in this case the court mistakenly executes the material right violating the law damaging the accused. Thus in this case none of the interviewed witnesses who were same time in capacity of injured parties did not see the accused at the crime scene to have taken any action towards the usurpation with concrete columns, even the brother of the accused interviewed in the capacity of the witness has stated how he himself with labors has surrender the real estate property with concrete columns with justification that he considered it as his real estate.

\section{Conclusions}

CCRK, in its law provisions, for comminting of criminal offence provides different punishmensts, with a level depending on criminal offence, therefore the court should be attentive regarding of imposing of level of punishment against the perpetrator of criminal offence

During the imposing of punishment of long life imprisonment, the court this type of punishment should impose only in sepcial serious cases based on all factors that have influenced to the criminal offence commitement

During the impose of punishment the court should take into consideration seriosly mitigating and aggrivating circumstances against the perpetratorWhen the court counts as mitigating and aggravating circumstances that have affected the determination of the level of the punishment, it not enough only to be counted, but for each menationed circumstance to givea special convincing justification

Onlythe imposition ofsentenceagainstthe defendant,inaccordancewith theseriousnessof the criminal offense, notto influence positively convicted andothers, butwillincreasesandstrengthenspublic confidencein the justice system.

When the law provides the posibillity to impose the alternative punishement, then the court considering theother circumstances, shouldimposethe punishment of fine, anditwillcome in consideration for the criminal offences which are not of serous nature

\section{Bibliography}

Bashkimi, Sh. (2010) Construction of Judicial Independent System in Kosovo/ Prishtina /Bashkimi, Sh. (2010) Ndërtimi i Sistemit Gjyqësor të Pavarur në Kosovë, Prishtinë.

Elezi, I. (2009) Criminal Right, special part, edition ERIK, Tirane/ Elezi, I. (2009) E drejta penale, pjesa e posaçme, Botimet ERIK, Tiranë.

Elezi, I. (2010) Criminal Right, special part edition ERIK, Tirane /Elezi, I. (2010) E drejta penale, pjesa e posaçme, Botimet ERIK, Tiranë.

Gashi, R. (2011) Organized Crime ,Prishtina/ Gashi, R. (2011) Krimi i Organizuar, Prishtinë.

Gleni, M.(2008) Mc Mafia - the crime without frontiers, Prishtine/ Gleni, M.(2008) Mc Mafija -krimi pa kufi, Prishtinë.

1 UNIK Regualtion nr. 2003/26 e dated Criminal Procedure Code in force from 06.042004 till 31.12.2012 06.07.2003. 
Hajdari, A. (2003) Criminal offence with corruption nature with a special view in Kosovo/ Hajdari, A. (2003) Vepra penale me natyrë korrupsioni me një vështrim të posaçëm në Kosovë - Prishtinë.

Hajdari, A. (2006) The right of Criminal Procedure Royal University ILIRIA, Prishitne / Hajdari, A. (2006) E drejta e procedures penale, Universiteti Mbretëror ILIRIA, Prishtinë.

Hajdari, A. (2013) The right of Criminal Procedure, special part, Prishtine / Hajdari, A. (2013) E drejta e procedures penale, Pjesa e posaçme, Prishtinë.

Hajdari, A. (2013) Judicial Practice skills, Prishtine/ Hajdari, A. (2013) Shkathtësitë e praktikës gjyqësore, Prishtinë.

Hajdari, A. (2013) Basic Judicial System, Prishtine/ Hajdari, A. (2013) Bazat e Sistemit gjyqësor, Prishtinë.

Halili, R. (2010) Penology, Prishtine/ Halili, R. (2010) Penologjia, Prishtinë.

Halili, R. (2011) Criminology. Prishtine/ Halili, R. (2011) Kriminologjia, Prishtinë.

Hoxha, B. (2005) Crime and Anti -Crime, tirane/Hoxha, B. (2005) KrimidheAntikrimi, Tiranë.

Nobert, M. (2005) Niediek Balcak Mafia, Shkup/Nobert, M. (2005) Niediek - Mafija e Ballkanit, Shkup.

Mëçalla, N. (2013) Money laundering, Edition House Klean, TiraneMëçalla, N. (2013) Pastrimi i Parave, Shtëpia Botuese Klean, Tiranë.

Jean, P. (2010) Geert Cortens, Gert Vermeuel, European Criminal Right, Papirus Jean, P. (2010) Geert Cortens, GertVermeuel, E Drejta Penale Evropiane, Papirus.

Kaçupi, S. Haxhia, M. (2012) Commentary of the Criminal Code of Republic of Kosovo, Tirane, aditted by KUMI./ Kaçupi, S. Haxhia, M. (2012) Komentari Kodit Penal të Republikës së Shqipërisë, Tiranë, Botimet KUMI.

Salihu, I. (1995) The Criminal Right, general part, Law Faculty, Prishitne/ Salihu, I. (1995) E drejta penale, pjesa e përgjithshme, Fakulteti Juridik, Prishtinë.

Salihu, I. (2010) the Criminal Right, general part, Law Faculty, Prishtine/Salihu, I. (2010) E drejta penale, pjesa e përgjithshme, Fakulteti Juridik, Prishtinë.

Muçi, Sh. (2012) the Criminal Right (general part) Edditing house "Dudaj", Tirana/ Muçi, Sh. (2012) E drejta penale (pjesa e përgjithshme) Shtëpia Botuese "Dudaj" Tiranë.

Shegani, A. (2005) Comparative Criminal Right, Tirane/Shegani, A. (2005) E drejta penale e krahasuar, Tiranë.

Vula, V. (2009) Cyber Criminality, Prishtine/ Vula, V. (2009) Kriminaliteti kompjuterik, Prishtinë.

\section{Criminal Codes}

Criminal Code of Kosovo/ Prishtine/ Kodi penal i Kosovës, (2003) Prishtinë.

Criminal Procedure Code of Kosovo, ( 2003) / Kodi i procedures penale i Kosovës, (2003) Prishtinë.

Criminal Code of Republic of Albania ( no. 7895 dated 27.01.1995) Tirane/ Kodi penal i Republikës së Shqipërisë, (nr.7895 dt.27.01.1995) Tiranë.

Criminal Procedure Code of Republic of Albania ( July 2007) Eddition of Public Centre , Tirane/ Kodi i Procedurës penale i Republikës së Shqipërisë (korrik 2007) Botimi Qendrës së Publikimeve Zyrtare, Tiranë.

Criminal nr.04/L-082 Code of Republic of Kosovo/ Kodionr.04/L-082 Penal i Republikës së Kosovës.

Criminal nr.04/L-123 Procedure of Republic of Kosovo/ Code of Kodi nr.04/L-123 i Procedurës penale i Republikës së Kosovës.

Code 03/L-193 of Justice for the juveniles of Republic of Kosovo/ Kodi nr.03/L-193 i Drejtësisë për të Mitur i Republikës së Kosovës. 